\title{
Clay-organic complexes in a Polish loess soil**
}

\author{
Ewa A. Czyz ${ }^{1 *}$, Jerzy Rejman ${ }^{2}$, Anthony R. Dexter ${ }^{3}$ Jan Jadczyszyn ${ }^{3}$, Anna Rafalska-Przysucha ${ }^{2}$, \\ and Jadwiga Stanek-Tarkowska \\ ${ }^{1}$ Department of Soil Science, Environmental Chemistry and Hydrology, Faculty of Biology and Agriculture, \\ University of Rzeszów, Zelwerowicza 8b, 35-601 Rzeszów, Poland \\ ${ }^{2}$ Institute of Agrophysics, Polish Academy of Sciences, Doświadczalna 4, 20-290 Lublin, Poland \\ ${ }^{3}$ Institute of Soil Science and Plant Cultivation (IUNG-PIB), Czartoryskich 8, 24-100 Puławy, Poland
}

Received February 5, 2016; accepted April 26, 2017

\begin{abstract}
A b s t r a c t. Complexes formed between clay and soil organic matter are important for carbon sequestration and for soil physical quality. Here, we use samples of loessial soil from South-East Poland to explore the phenomenon of complexing in loess. Soil samples were collected from a single catchment 8 years after the introduction of strip tillage and their compositions were characterized by traditional methods. Complexing was characterized in terms of the content of non-complexed clay which was estimated in two ways: firstly, by measurement of the content of readilydispersible clay (which was assumed to be the non-complexed clay); and secondly, by calculation using algorithms that had been developed and evaluated previously. The calculations were based on the concept that, at carbon saturation, the clay/organic carbon mass ratio is equal to $n$. The calculations were done with a range of values of $n$. It was assumed that the correct value of $n$ was that which gave the greatest coefficient of correlation between the measured values of clay dispersion and the predicted values of non-complexed clay. For the loess used, the optimum value was $n=14$.
\end{abstract}

K e y w o r d s: carbon sequestration, clay dispersion, complexed organic matter, non-complexed clay, strip tillage

\section{INTRODUCTION}

The theory of complexing is based on the concept that one unit (by mass) of clay can form a complex with $n$ units of organic carbon $(O C)$ when $n$ is the clay/organic carbon mass ratio at carbon saturation. Here, the term complex is used to describe a structure formed by bonding between the clay particles and organic molecules. It is organic matter $(O M)$ that forms complexes, although it is $O C$ that is usually measured in the laboratory and which is therefore used in most calculations. We take the $O M$ content to be equal to 1.724

*Corresponding author e-mail: ewac@ur.edu.pl

**This work was supported financially by Polish National Science Centre grant No. NCN 2012/07/B/N29/02340 (2013-2016). $\mathrm{x} O C$, where $O C$ is the organic carbon content and 1.724 is the mean value of the coefficient as found by Howard (1965). In arable soils, the majority of the organic matter is in decomposed, molecular forms. In this paper, we do not consider partially-decomposed forms of organic matter such as $P O M$ (particulate organic matter).

The structures produced in this complexing have no stoichiometry because of the wide range of sizes and charge distributions on both the clay particles and the organic molecules. The clay-organic complex in soil has been found to have a very small effective mean density of $170 \pm 40 \mathrm{~kg} \mathrm{~m}^{-3}$ (Czyż and Dexter, 2016). This is a smaller density than that of any other component of soil or of the whole soil. Such a small value of density can come only from a very open structure, perhaps similar to those of micelles or clathrates (Manjaiah et al., 2010). This low density of complexes provides an explanation for the observed decrease in soil density with increasing concentration of $O M$. The complexing stabilizes the clay and thereby gives it a degree of protection against dispersion in water (Dexter et al., 2008; Emerson et al., 1986; Hassink and Whitmore, 1997). Dexter et al. (2008) showed that, whereas non-complexed clay disperses readily in water, the complexed clay does not. This is an explanation for the observed increase in soil stability in water with increased content of $O M$.

Non-complexed clay may be estimated in two ways: - experimentally: by adjusting the water content of soil sub-samples in a standard way, adding a sub-sample to a given volume of pure water, and then shaking the resulting suspension with a small input of mechanical energy. The amount of clay in suspension after $16 \mathrm{~h}$ of

(C) 2017 Institute of Agrophysics, Polish Academy of Sciences 
sedimentation is then measured by turbidimetry in terms of the scattering of a light beam. It has been shown experimentally that it is the non-complexed clay that is readily-dispersible clay $(R D C)$ (Dexter et al., 2011) and

- by calculation: the extent of complexing depends on the mass concentrations of clay and $O M$ in the soil. Complexing results in the occurrence of complexed clay $(C C)$, non-complexed clay (NCC), complexed organic carbon $(C O C)$ and non-complexed organic carbon (NCOC). These can be calculated using the following algorithms as introduced by Dexter et al. (2008):

$C C=(n O C)$ if $n O C<$ clay $)$, else $C C=$ clay,

$N C C=($ clay $-C C)$ if $($ clay $-C C)>0$, else $N C C=0$,

$C O C=O C$ if $(O C<$ clay $/ n)$, else $C O C=($ clay $/ n)$,

$N C O C=(O C-C O C)$ if $(O C-C O C)>0$, else $N C O C=0$.

A practical, working value of $n=10$ for the soils that they used was determined from clay dispersion measurements by Dexter et al. (2008). This concept has been evaluated independently by Schjønning et al. (2011) for samples of 64 Danish soils and found to be valid. Getahun et al. (2016) came to the same conclusion. Schjønning et al. (2011) showed that this approach can also be used with 'fines 20 ' (i.e. particles $<20 \mu \mathrm{m}$ ) instead of clay. This required a value of $n=20$. However, for the purposes of this paper we have used clay because values of clay concentration are more widely used and available.

A special case is when the clay and the $O M$ are balanced and when both $N C C=0$ and $N C O C=0$. This occurs when the clay is saturated with $O M$; that is, when any additional $O M$ would not find any non-complexed clay with which to form a complex. The pairs of Eqs (1) and (2) and also of Eqs (3) and (4) give for the condition when saturation occurs:

$$
O C_{\text {sat }}=c l a y / n .
$$

We introduce a factor $X$ that is useful for cases where the $O M$ is not sufficient to saturate the clay. In practice, this is the case for most arable soils for which $X<1.0$. Nontilled soils, such as permanent pasture can have $X>1.0$, which we call carbon super-saturation. The condition $X>$ 1.0 can lead to peat formation. The phenomenon of carbon saturation $(X=1.0)$ has been shown to occur in the field (Schjønning et al., 2011; Stewart et al., 2007). Carbon saturation $X=1.0$ is found to produce optimum soil physical quality as quantified by the index $S=0.05$ (Dexter et al., 2008). Non-complexed clay, $N C C$, reduces soil physical quality by decreasing the soil stability in water, decreasing the soil friability, and by causing soil hard-setting and crust formation (Kay and Dexter, 1992; Shanmuganathan and Oades, 1982; Watts and Dexter, 1997).

We conjecture that complexing provides a degree of physical/chemical protection of organic matter against microbial decomposition. If this is true then we can say that clay-organic complexing can play an important role in carbon sequestration in soil. For example, complexed $O M$ is relatively stable against the energy inputs from tillage (Watts and Dexter, 1997) whereas non-complexed $O M$ is not.

We may expect that the value of $n$ will be different for soils containing different clay minerals because of differences in the specific surface areas and the surface charge distributions. Also, it is possible that the different quality of organic matter originating from different types of plants may affect the value of $n$. However, within the relatively small catchment area studied, we may reasonably expect that these factors are not present.

In this paper, we focus specifically on clay-organic complexing in a Haplic Luvisol formed on loess. Up until now, there has not been any work that concentrates on complexing in these soils. We approach this subject by considering the contents of clay and organic carbon in a set of soil samples freshly collected from the field.

\section{MATERIALS AND METHODS}

Soil samples were collected in 2014 from a catchment of 11.5 ha on a private farm used for cereal production at Rogów in South-Eastern Poland. The position of the experimental site was measured by GPS. The farm is in the loess area of Działy Grabowieckie (Lublin Upland, Poland) where the mean annual precipitation is $663 \mathrm{~mm}$ and the mean air temperature is $8.3^{\circ} \mathrm{C}$.

The catchment had been managed consistently for the previous 8 years with a 3 -year crop rotation: winter wheat, rape, and maize with retention of crop residues. Prior to these experiments, the catchment had been mouldboard ploughed, but since the start of the experiment in 2006, strip tillage had been practiced. Strip tillage is a conservation tillage system in which the soil is disturbed only where the crop rows will be (Evans et al., 2010). The catchment was mapped using GPS.

Soil samples were collected in Spring from a grid of 93 points in the catchment from 3 depth ranges $(0-150,150$ 300 , and $300-500 \mathrm{~mm}$ ). This gave a total of 279 points $\mathrm{x}$ depths. The points in the grid were spaced $20 \mathrm{~m}$ apart. At each sampling point, samples were collected from a small area $\left(1 \mathrm{~m}^{2}\right)$ for measurement of all physical and chemical properties. The soil samples were collected from such small areas in order to minimize variation in the properties measured at each point. It is a general principal in geostatistics that, on average, variation increases with increasing distance between sampling points (Webster and Oliver, 2007). 
Because of differential erosion and deposition processes in the catchment, the samples had a range of compositions. The measurements were made using standard laboratory methods as follows. Particle size distributions were measured by sedimentation by the pipette method. This enabled the content of clay (mineral particles $<2 \mu \mathrm{m}$ ) to be determined. Organic carbon measurements were measured by wet oxidation. The measurements were done by sulfochromic oxidation of organic carbon (ISO, 1998) followed by titration of the excess of $\mathrm{K}_{2} \mathrm{Cr}_{2} \mathrm{O}_{7}$ with $\mathrm{FeSO}_{4}\left(\mathrm{NH}_{4}\right)_{2} \mathrm{SO}_{4}$ $6 \mathrm{H}_{2} \mathrm{O}$. Gravimetric water contents were measured by oven-drying at $105^{\circ} \mathrm{C}$ for $24 \mathrm{~h}$. The samples were collected with minimum disturbance and were stored until measurement in a cool place at constant (field) water content.

The amount of readily-dispersible clay in water was measured following a standard dilution and shaking procedure using turbidimetry. The turbidimeter readings were expressed as NTU (Nephelometric Turbidity Units) and were normalized by dividing by the concentration of the original soil in the water to give NTU/( $\left.\mathrm{g}^{-1}\right)$. For each soil sample, 5 sub-samples were used. For each sub-sample about $5 \mathrm{~g}$ of soil were weighed and placed in $150 \mathrm{ml}$ calibrated plastic bottles and then de-ionized water was added to make $125 \mathrm{ml}$. It was important to maintain constant volume of the air bubble in the bottles of $150-125=25 \mathrm{ml}$ because this affects the mechanical energy input. A larger air bubble increases the energy input. It was also important to use samples that had not dried because drying can reduce clay dispersion (Dexter et al., 2011).

The bottles were subjected to mechanical energy in a standardized way (four inversions end-over-end). The bottles were then allowed to stand for $18 \mathrm{~h}$ so that the larger particles would sediment, leaving only dispersed colloids (in this case, mostly clay) in suspension. A $30 \mathrm{ml}$ sample of this suspension was extracted by pipette from the centre of each bottle and was transferred to a glass turbidity cell. The turbidity measured, $T_{R D C}\left(\mathrm{NTU} /\left(\mathrm{g} \mathrm{l}^{-1}\right)\right)$, was assumed to be proportional to the concentration of $R D C$ in the sample.

At the same time, a further 5 sub-samples of each soil sample were prepared for determination of total clay. In this case, the same ratio of soil to water was used as before but larger quantities were required to provide enough space for a stirrer. About $18 \mathrm{~g}$ of soil were weighed and placed in 750-1000 ml Berzelius glasses and were stirred intensively with $500 \mathrm{ml}$ distilled water for $30 \mathrm{~min}$. Then $125 \mathrm{ml}$ from this suspension was poured into the plastic bottles and allowed to stand for $18 \mathrm{~h}$ so that the larger particles would sediment, leaving only colloids (clay) in suspension. A $30 \mathrm{ml}$ sample of this suspension was extracted by pipette from the centre of each bottle and was transferred to a glass turbidity cell. The turbidity measured, $T_{\text {clay }}\left(\mathrm{NTU} /\left(\mathrm{g} \mathrm{l}^{-1}\right)\right)$, was assumed to be proportional to the concentration of total clay in the sample.
The mass concentration of $R D C\left(\mathrm{~g} \mathrm{~kg}^{-1}\right)$ in the sample was calculated by multiplying the soil clay content $\left(\mathrm{g} \mathrm{kg}^{-1}\right)$ as measured in the laboratory using the standard sedimentation method by the ratio $\left(T_{R D C} / T_{\text {clay }}\right)$.

The turbidity of the suspensions in the turbidity cells was measured by light-scattering using a Hach 2100AN ratio turbidimeter (Hach Company, Loveland, Colorado, U.S.A.) as illustrated in Czyż and Dexter (2008). This apparatus is linear over a huge range of turbidities (manufacturer literature). Turbidity values are linearly proportional to the concentration of colloids (clay) in suspension (Dexter and Czyż, 2000). The mass of soil in each sample was corrected to dry mass for this calculation using the measured water contents. Five replicates were used for each soil and depth at each place. The total number of sub-samples that were measured was 2790 (279 samples $\times 10$ sub-samples). The mean values for each of the 279 samples were used.

The turbidimeter was calibrated using the measurements of the concentration of soil clay in suspension as obtained from the analysis of particle size distribution, clay, and the measured turbidities of the suspensions after 30 min intensive mechanical stirring, $T_{30}$. The clay contents were in units of grammes of clay in suspension / $\mathrm{kg}$ water, whereas the turbidimeter readings were in units of NTU/ (grammes of soil / $\mathrm{kg}$ water). The masses of soil were corrected to dry mass using measured water contents.

For each sample, the proportion of clay that is readilydispersible, $P_{R D C}$, was calculated as:

$$
P_{R D C}=T_{R D C} / T_{\text {clay }},
$$

and the proportion of clay that is non-complexed, $P_{N C C}$, was calculated using Eqs ( 1 and 2) for a range of values of $n$ for each sample as:

$$
P_{N C C}=N C C /(N C C+C C)=N C C / \text { clay, }
$$

Correlation coefficients between the 279 values of $P_{R D C}$ and the corresponding 279 values of $P_{N C C}$ were calculated for values of $n$ in the range 1 to 20 .

\section{RESULTS AND DISCUSSION}

The catchment included the point: latitude $50^{\circ} 47^{\prime} 57^{\prime \prime}$ $\mathrm{N}$ and longitude $23^{\circ} 29^{\prime} 28^{\prime \prime} \mathrm{E}$ which gives a representative position of the experiment. We do not present a contour map of the catchment because in this paper we consider soil properties without reference to their position. The mean concentrations of clay, organic carbon and $R D C$ in the soil samples are given in Table 1.

The results presented in Table 1 show that the soil from Rogów is a silt loam (loess). According to the FAO system of soil classification (FAO, 1988), the soil is a Haplic Luvisol. A study on another loessial catchment in the same part of Poland was done by Rejman (2013) and this may be used for comparison. It can be seen in Table 1 that, whereas, on average, the clay content is uniform with depth, 
the organic matter content is greatest near to the surface. With mouldboard ploughing, the input of mechancal energy is considerable resulting in an increase in $R D C$ and corresponding loss of stability of the soil in water. With mouldboard ploughing the intense mechanical disturbance involved encourages tillage erosion and also the plough layer becomes thoroughly mixed with the result that the content of $O C$ becomes uniform down to the depth of tillage. In contrast, a system of reduced tillage, such as the strip tillage used here, applies much less mechanical energy to the soil thereby reducing tillage erosion. It also results in greater concentration of organic matter (and hence $O C$ ) adjacent to the soil surface thereby reducing the concentration of NCC with consequent increased stability and physical quality of this surface soil (Gațe et al., 2002; Czyż and Dexter, 2008). The increased stability in water of the surface soil reduces its erodibility by water. It can be seen that the type of tillage system used mainly modifies the distribution of organic matter with depth with consequences for soil behaviour in the field.

The calibration equation of the turbidimeter was determined as:

$$
\text { clay }=(5.11 \pm 0.26) T_{30},
$$

where: the coefficient is the geometric mean of the values obtained for the 279 soils separately.

The water contents of the soil samples used for measurement of $R D C$ ranged from:

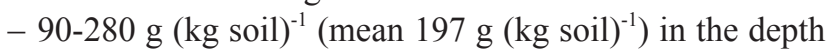
range $0-150 \mathrm{~mm}$;
- 110-250 $\mathrm{g}(\mathrm{kg} \mathrm{soil})^{-1}\left(\right.$ mean $\left.190 \mathrm{~g}(\mathrm{~kg} \mathrm{soil})^{-1}\right)$ in the depth range $150-300 \mathrm{~mm}$;

- 100-260 $\mathrm{g}(\mathrm{kg} \text { soil })^{-1}\left(\right.$ mean $\left.197 \mathrm{~g}(\mathrm{~kg} \text { soil })^{-1}\right)$ in the depth range $300-500 \mathrm{~mm}$.

These values of water content were sufficient for determination of $R D C$ (Dexter et al., 2011).

As expected for soils formed on eolian deposits, the soil is stone-free, and has a particle size distribution that, on average, does not vary with depth as shown in Table 1 for the range of depths $0-500 \mathrm{~mm}$. We conjecture that variations in particle size distribution between individual sampling points is a result of illuviation and erosional/ depositional processes including both water and tillage erosion (Rejman, 2013).

The 279 values of the proportions of clay that is non-complexed (measured as RDC by turbidimetry and calculated using Eq. (6)) were compared with the 279 values of the proportions of clay that is non-complexed (calculated using Eq. (7)) for different values of $n$ using Eqs (1-4). This comparison was done by examining the values of the correlation coefficient, $r$, between the two sets of data.

Figure 1 shows that the maximum value of correlation coefficient occurred at $n=14$ and we assume that this is the appropriate value to use in Eqs (1-5). This is in contrast with Dexter et al. (2008) who used the value of $n$ at a pronounced inflection point in the curve of $r$ against $n$ for the soils that they used. However, in the present work we have not found any inflection point, but a maximum. We do not understand why these results are different. A possible explanation is that in the earlier work, a wide range of soil

T a b I e 1. Mean compositions ( $\left.\mathrm{g}(\mathrm{kg} \text { soil })^{-1}\right)$ of the examined soils at three depths. Numbers in parenthesis give the range of values obtained experimentally

\begin{tabular}{|c|c|c|c|c|c|c|c|c|c|c|}
\hline \multirow{4}{*}{$\begin{array}{l}\text { Depth } \\
(\mathrm{mm})\end{array}$} & \multicolumn{6}{|c|}{ Particle size $(\mathrm{mm})$} & \multirow{2}{*}{\multicolumn{2}{|c|}{$O C$}} & \multirow{2}{*}{\multicolumn{2}{|c|}{$R D C$}} \\
\hline & \multicolumn{2}{|c|}{ Sand (2-0.063) } & \multicolumn{2}{|c|}{ Silt (0.063-0.002) } & \multicolumn{2}{|c|}{ Clay $(<0.002)$} & & & & \\
\hline & \multicolumn{10}{|c|}{$\mathrm{g}(\mathrm{kg} \text { soil })^{-1}$} \\
\hline & $\begin{array}{c}\text { Mean } \\
\text { (min-max) }\end{array}$ & SD & $\begin{array}{c}\text { Mean } \\
\text { (min-max) }\end{array}$ & $\mathrm{SD}$ & $\begin{array}{c}\text { Mean } \\
\text { (min-max) }\end{array}$ & SD & $\begin{array}{c}\text { Mean } \\
\text { (min-max) }\end{array}$ & SD & $\begin{array}{c}\text { Mean } \\
\text { (min-max) }\end{array}$ & SD \\
\hline $0-150$ & $\begin{array}{c}15 \\
(8-26)\end{array}$ & 4 & $\begin{array}{c}846 \\
(759-907)\end{array}$ & 24 & $\begin{array}{c}139 \\
(84-222)\end{array}$ & 23 & $\begin{array}{c}9.0 \\
(4.3-16.8)\end{array}$ & 1.7 & $\begin{array}{c}37.3 \\
(13.0-99.7)\end{array}$ & 16.2 \\
\hline $150-300$ & $\begin{array}{c}14 \\
(8-26)\end{array}$ & 4 & $\begin{array}{c}846 \\
(770-900)\end{array}$ & 25 & $\begin{array}{c}140 \\
(90-213)\end{array}$ & 25 & $\begin{array}{c}6.7 \\
(2.0-10.4)\end{array}$ & 2.2 & $\begin{array}{c}41.8 \\
(14.2-88.1)\end{array}$ & 17.9 \\
\hline $300-500$ & $\begin{array}{c}14 \\
(8-28)\end{array}$ & 4 & $\begin{array}{c}848 \\
(771-931)\end{array}$ & 33 & $\begin{array}{c}138 \\
(60-220)\end{array}$ & 33 & $\begin{array}{c}3.5 \\
(1.2-8.0)\end{array}$ & 1.9 & $\begin{array}{c}54.8 \\
(11.9-127.0)\end{array}$ & 24.2 \\
\hline
\end{tabular}

$O C$ - soil organic carbon, $R D C$ - readily-dispersible clay, $S D$ - standard deviation. 


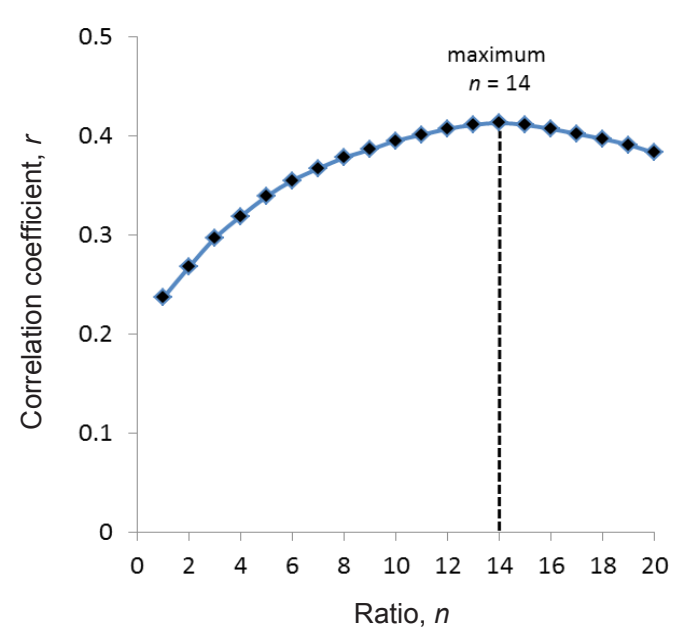

Fig. 1. Plot of the correlation coefficient, $r$, between measured suspension turbidities and the value of $n$ used to estimate the contents of complexed and non-complexed organic carbon and clay using Eqs (1-4). Maximum correlation occurs at $n=14$.

types and textures was used; whereas in the present work, only one soil type was used. It was also found that the coefficients of correlation, $r$, were greater in the earlier work (typically $r=0.6$ ) than in this work (typically $r=0.5$ ).

The use of the value of $n=14$ in combination with measured clay and organic carbon concentrations enables the concentrations of $C C, N C C, C O C$ and $N C O C$ to be estimated using Eqs (1-4). The use of this value of $n$ in combination with measured clay concentrations enables the concentration of organic carbon at saturation to be estimated using Eq. (5). Use of the values in Table 1 in combination with Eq. (5) shows that the surface layer $(0-150 \mathrm{~mm})$ in this soil was close to saturation with organic matter at the time of sampling. It is also possible to use our results to estimate the carbon saturation deficit, $O C_{d e f}$, based on the difference between the carbon concentrations at saturation and the actual carbon concentrations. We may write this as follows:

$$
O C_{d e f}=O C_{\text {sat }}-O C \text {, }
$$

where $O C_{\text {sat }}$ may be obtained from Eq. (5). This provides a practical way of estimating the additional amount of carbon that soil can sequester sustainably. This is important in climate change research where it is required to quantify the ability of soil to store carbon taken from the atmosphere by photosynthesis thereby reducing global warming.

Future work could include studies of the effects of clay - organic complexes on the physical behaviour of loessial soils and the relationships with position in the landscape. Also, some fundamental questions remain about the effects of different clay minerals and organic matter from different sources on complexing and on the resulting values of $n$.

\section{CONCLUSIONS}

1. Correlations between measured values of readilydispersible clay and calculated values of non-complexed clay provide us with a method to determine the value of $n$. The value of $n$ is a measure of how much organic carbon is complexed with unit mass of clay in the experimental soils.

2 . The value $n=14$ gave the maximum correlation between the measured and the calculated values for the loess soils studied.

3. For these loess soils, the average concentration of organic carbon when the complex is saturated with organic matter is given as 0.07 clay $\left(\mathrm{g} \mathrm{kg}^{-1}\right)$. The surface layer of this soil is close to saturation with organic matter. Organic matter at concentrations smaller than this may be considered to be sequestered.

4. The theory and procedures described provide the basis for the estimation of the carbon saturation deficit which is the additional amount of carbon that soils can sequester. This is important in relation to climate change where the removal of carbon from the atmosphere is of vital importance.

\section{ACKNOWLEDGEMENTS}

The authors wish to thank Mr. W. Gryn for permission to collect soil samples from his farm.

Conflict of interest: Authors do not declare any conflict of interest.

\section{REFERENCES}

Czyż E.A. and Dexter A.R., 2008. Soil physical properties under winter wheat grown with different tillage systems at selected locations. Int. Agrophysics, 22, 191-200.

Czyż E.A. and Dexter A.R., 2016. Estimation of the density of the clay-organic complex in soil. Int. Agrophys., 30, 19-23. doi: 10.1515/intag -2015-0075

Dexter A.R. and Czyż E.A., 2000. Effects of soil management on the dispersibility of clay in a sandy soil. Int. Agrophysics, 14, 269-273.

Dexter A.R., Richard G., Arrouays D., Czyż E.A., Jolivet C., and Duval O., 2008. Complexed organic matter controls soil physical properties. Geoderma, 144, 620-627. doi: 10.1016/j.geoderma.2008.01.022

Dexter A.R., Richard G., Czyż E.A., Davy J., Hardy M., and Duval O., 2011. Clay dispersion from soil as a function of antecedent water potential. Soil Sci. Soc. Amer. J., 75(2), 444-455. doi: 10.2136/sssaj2010.0088

Emerson W.W., Foster R.C., and Oades J.M., 1986. Organomineral complexes in relation to soil aggregation and structure. In: 'Interactions of Soil Minerals with Natural Organics and Microbes', Chapter 14, 521-548, Special Publ. No. 17, Soil Sci. Soc. Amer., Madison, WI, USA.

Evans R.G., Stevens W.B., and Iversen W.M., 2010. Development of strip tillage on sprinkler irrigated sugarbeet. Appl. Eng. Agric., 26(1), 59-69.

FAO, 1988. FAO/UNESCO Soil Map of the World, Revised 
Legend, with corrections and updates. World Soil Resources Report 60, FAO, Rome. Reprinted with updates as Technical Paper, 20, ISRIC, Wageningen, 1997.

Gațe O.P., Czyż E.A., and Dexter A.R., 2004. Effects of readilydispersible clay on soil quality and root growth. In: Plant Growth in Relation to Soil Physical Conditions (Eds J. Lipiec, R. Walczak, G. Józefaciuk). IA PAS Press, Lublin, Poland.

Getahun G.T., Munkholm L.J., and Schønning P., 2016. The influence of clay-to-carbon ratio on soil physical properties in a humid sandy loam with contrasting tillage and reduced management. Geoderma, 264, 94-102. doi: 10.1016/j. geoderma.2015.10.002

Hassink J. and Whitmore A.P., 1997. A model of the physical protection of organic matter in soils. Soil Sci. Soc. Amer J., 61(1), 131-139. doi: 10.2136/sssaj1997.036159950061000 10020x

Howard P.J.A., 1965. The carbon-organic matter factor in various soil types. Oikos, 15(2), 229-236. doi: 10.2307/3565121

ISO, 1998. Soil quality - determination of organic carbon in soil by sulfochromic oxidation. ISO 14235, Geneva, Switzerland.

Kay B.D. and Dexter A.R., 1992. The influence of dispersible clay and wetting/drying cycles on the tensile strength of a red-brown earth. Aust. J. Soil Res., 30(3), 297-310. doi: 10.1971/SR9920297
Manjaiah K.M., Kumar S., Sachdev M.S., Sachdev P., and Datta S.C., 2010. Study of clay-organic complexes. Current Science, 98(7), 915-921.

Rejman J., 2013. Redistribution of basic physical properties and water content of soils in a loess catchment. Acta Agrophysica Monographiae, 5, 1-107.

Schjønning P., de Jonge L.W., Munkholm L.J., Moldrup P., Christensen B.T., and Olesen J.E., 2011. Clay dispersibility and soil friability - testing the soil clay-to carbon saturation concept. Vadose Zone J., 11(1), doi: 10.2136/ vzj2011.0067

Shanmuganathan R.T. and Oades J.M., 1982. Effects of dispersible clay on the physical properties of the B-horizon of a red-brown earth. Aust. J. Soil Res., 20, 315-324. doi: 10.1071/SR9820315

Stewart C.E., Paustian K., Conant R.T., Plante A.F., and Six J., 2007. Soil carbon saturation: concept, evidence and evaluation. Biogeochemistry, 86(1), 19-31. doi: 10.1007/ s10533-007-9140-0

Watts C.W. and Dexter A.R., 1997. The influence of organic matter in reducing the destabilization of soil by simulated tillage. Soil Tillage Res., 42, 253-275. doi: 10.1016/S10671987(97)00009-3

Webster R. and Oliver M.A., 2007. Geostatistics for Environmental Scientists. John Wiley and Sons Ltd., Chichester, England. 